\title{
Institutional design, informal practices and international conflict: The case of community-based pasture management in the Kyrgyz-Tajik border region
}

\author{
Gulzana Kurmanalieva ${ }^{1}$ and Wibke Crewett $^{2^{*}}$
}

\begin{abstract}
In the Kyrgyz Region of Ferghana Valley, violent conflict flares repeatedly between the local Kyrgyz majority population and the Tajik ethnic minority. Drawing on a recent qualitative case study conducted in the borderlands of one of the two Tajik enclaves within the Kyrgyz Batken Region, this article seeks to identify the causes of pasturerelated inter-ethnic conflict in the agro-pastoral Kyrgyz-Tajik border region. The paper employs an institutional perspective and explores the impact of the given institutional setup. We note that a lack of institutional arrangements for transboundary pasture use hinders Tajik herders' legal access to the region's sole summer pastures. The Kyrgyz "Pasture Committee" has pragmatically designed local rules on transboundary pasture use in the Kyrgyz-Tajik border region, thereby assuring Tajik herders at least semi-official access to the summer pastures. Yet while these rules limit conflict, they fail to limit overstocking. Locally designed rules also open up business opportunities to Tajik herders, which some of the Kyrgyz herders consider unfair and illegal. In order to achieve sustainable and locally accepted regional pasture management, despite the lack of legislative amendments and international agreements, we propose local-level institutional innovations. We also emphasize that pasture use regulation is paramount for maintaining regional stability and peaceful cooperation.
\end{abstract}

Keywords: Property rights, Pastures, Institutions, Ferghana valley, Conflict, Community-based management

\section{Introduction}

Conflicts over the use of natural resources located in the transboundary regions of Tajikistan and Kyrgyzstan are an ongoing challenge to peaceful relationships between the two countries. The formal constitutions of the five independent Central Asian nation states which came into effect in the 1990s, after the breakup of the USSR, cemented the mainly nominal Soviet Republics' borders which were established during the 1920s and 1930s. The current border lines are still not always clear and are frequently contested. Of the 971-km border dividing Kyrgyzstan and Tajikistan, only $519 \mathrm{~km}$ has been officially agreed upon (Matveeva 2017). Since the turn of the millennium, moreover, resurgent nationalism accompanied by growing expectations of specifically national

\footnotetext{
* Correspondence: wibke.crewett@mailbox.org

${ }^{2}$ Humboldt-Universität zu Berlin, Unter den Linden 6, 10099 Berlin, Germany Full list of author information is available at the end of the article
}

territorial rights has fueled inter-ethnic tensions over the use of valuable natural resources in border areas, particularly in densely populated, ethnically mixed regions such as the fertile Ferghana valley studied here (Reeves 2014), and conflict over transboundary resource use is therefore rife. Seasonal livestock migration has generally shrunk in scope (Kerven et al. 2011; Kerven et al. 2012), yet it nonetheless remains vital to the survival of a rural population dependent for its livelihood on livestock herding and hence also on the strategic use of transboundary rangelands. The situation in eight exterritorial communities, so-called enclaves, of which six lie in the Ferghana valley in the west of Kyrgyzstan, has proved especially problematic.

This article therefore focuses on conflicts over transboundary pasture use in and around Tajik enclave in the Batken Region, Kyrgyzstan. Kyrgyz media have reported that violent conflicts erupt there between Kyrgyz and 
Tajik herders over their use of summer pastures. Escalating inter-ethnic clashes in the period ca. 2000-2013 are sometimes referred to as the "ketmen war", because the Tajik and Kyrgyz communities resorted to using agricultural hoes (ketmen) and stones as weapons. They also used arson (burning down animal shelters on the summer pastures, for example), held hostages ransom, and left a number of people injured (Toktomushev 2017). A review of the available grey literature, exclusively commissioned by non-governmental organizations, shows that local non-governmental organizations's staff considers the currently inadequate institutional framework to be the "root cause" of these conflicts. They agree that this framework fails to allocate clearly specified land rights (i.e. pasture rights) to both Kyrgyz and Tajik herders: the latter suffer severe discrimination.

Yet the international scientific literature on transboundary rangeland conflicts in Central Asia is very limited. While there is some literature on transboundary water use conflicts in Central Asia (e.g. Vinogradov and Langford 2001; Mosello 2008; Sehring 2009; Abdullaev et al. 2006; Bichsel 2009) and on transboundary pasture use conflicts in other parts of the world (e.g. Beyene 2009; Hundie 2010; Zelalem and Bayeh 2014), pasture use conflicts in Central Asia have not received much attention (Kerven et al. 2011). Exceptions can be found in Dörre (2016) and Lim (2012), who explore frictions in the Kyrgyz and Tajik legislation on pasture use.

In this article, we seek to identify which local-level working rules on the governance of access to transboundary rangelands in Central Asia have been drawn up in light of that which previous research had identified as "inappropriate formal property rights" (see Lim 2012).

\section{Analytical and theoretical framework}

The Institutions of Sustainability (IoS) framework (Hagedorn et al. 2002; Hagedorn 2008) serves to structure holistic studies on nature-related social-ecological interaction from an institutional economics perspective. It has been widely applied in studies of the impact of property rights on natural resource use (e.g. Hamidov and Thiel 2011; Crewett 2015a, 2015b; Prager 2010). In the present study, we adopt the central premise of the IoS, according to which the properties of the respective transactions and the characteristics of the actors involved determine which institutions (sets of rules) develop, as well as through which governance structures (organizational forms) these institutions will be implemented in practice. When applying the IoS, we use the interlinked theoretical elements: (a) the nature-related transaction, (b) the characteristics of actors, (c) the governance structure, and (d) the institutions, but we also put some extra emphasis on working rules that we have observed in the field (see Fig. 1).

In our study, the transaction is defined as "livestock summer grazing by the residents of two neighboring municipalities in the Kyrgyz-Tajik borderland". We thereby follow Hagedorn's definition of a transaction according to which " $\mathrm{t}]$ he only requirement for an action to be also called a transaction is that the actors involved are affected due to a physical implication. [ ... ] We only assume that it always has some form of physical realization that is relevant for the actors involved. Obviously, a transaction [ ... ] is induced by a decision [that is taken by] one or more actors, and affects one or more actors" (Hagedorn 2008, 6-7). The studied transaction in our case is a conflict that arises when Kyrgyz and Tajik livestock raisers express differing perspectives on

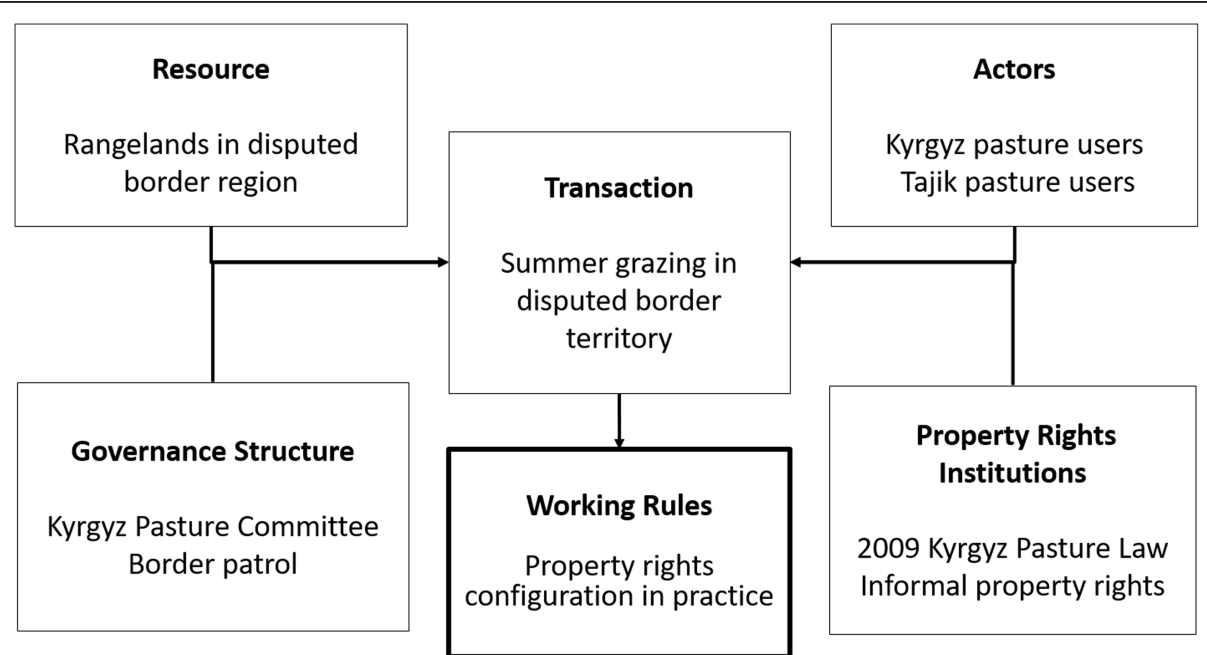

Fig. 1 Analytical framework 
their respective rights to use certain summer pastures. In this article, we use a slightly modified definition from Cabot (2017), according to which "a conflict is the opposition between two or more individuals or groups with opposing interests, concerning the way to deal with an issue" (Cabot 2017, 30), and may involve violence.

We define institutions as "systems of established rules, conventions, norms, values and customs" (Fleetwood 2008, 247). Institutions embody "collective action in the control, liberation, and expansion of individual action" (Commons 1931, 648), and in consequence, they determine the scope of action open to actors involved in a studied transaction. In this study, we focus on property rights. Property rights are a specific form of institution that determines a person's right to enjoy defined benefit streams (Bromley 1991) that ensue from the use of assets or resources. They therefore distribute authority (Libecap 1989), power (Eggertsson 1996, 14), and wealth (Libecap 1989; Wiebe and MeinzenDick 1998) within society, and they specify the position of the actor with respect to resource utilization (Furubotn and Pejovich 1972). The configuration of property rights is accordingly a very common source of conflict and a most critical field of study in institutional economics. Property rights in our case study are defined by the locally designed rules governing the use of summer pastures in the KyrgyzTajik borderlands for grazing livestock.

Institutions differ with regard both to their respective enforcement mechanisms and the degree of formality these mechanisms have. Formal institutions are enforced by means of formal legislation and the state. However, the enforcement of informal institutions is based on unwritten rules and is executed by non-state actors (e.g. Ostrom 2005, 139-174). The governance structure that is implicit in any transaction can be defined as a group of actors endowed with a bundle of rights to regulate the transaction by enforcement of the existing set of institutions. In our study, the governance structure is the legally defined community-based management body.

We depart from the original IoS in which working rules are only implicit. In our framework, we consider working rules as a specific set of de facto rules that govern any given real-world situation. Such rules are "common knowledge" and every actor "knows the rules, and knows that others know the rules" (Ostrom 1990, 51). Working rules might contain elements of the legal formal rules, of the existing informal rules, and of the newly designed rules which are effectively used, monitored, and "at least to some extent" enforced (Ostrom 1990, 51).

Our adapted framework allows us to study the working rules that result from the interaction of all the elements in the framework. It also helps us study how (if at all) "governance" as postulated in Institutional Economics serves to "craft order [and] thereby to mitigate conflict and realize mutual gains" (Williamson 2000, 599).

\section{Study area}

A Kyrgyz municipality (henceforce referred to as Municipality A) located in the transboundary rangelands of Kyrgyzstan and Tajikistan, which shares a border with the neighbouring Tajik enclave municipality (henceforth referred to as Municipality B). According to the most recent maps, the transboundary rangelands are Kyrgyz territory. However, many Tajik herders depend for their livelihood on the use of these pastures.

The Kyrgyz municipality A is located at an altitude of $1200 \mathrm{~m}$ above sea level. At the time of data collection, it had 7500 inhabitants (NSC 2015). Seasonal migration from May to October is part of the dominant production system of raising livestock. In 2015, the total number of cattle, sheep, goats, and horses was 21,774 animals (NSC 2015). Official statistics are, however, unreliable and likely to underestimate the true number of animals grazing on the pastures.

\section{Methodology}

Multiple data sources were used for the case study analysis, including a review of the formal legislation, document analysis, expert and household interviews, and observations at the study site. During field research in September 2015 and August 2016, 35 semi-structured and open expert interviews (Bogner et al. 2009) were conducted with individuals purposely selected from non-governmental and governmental agencies, as well as with herding practitioners from Municipality A and Municipality B (Table 1). Qualitative content analysis (Mayring 2000) was deployed, namely by using inductive and deductive coding for analysis of the original interviews and documents.

\section{Findings}

In this section, we first describe the contested resource ("The status of the contested pasture resource" section) and then explore the features of the identified transaction ("The transaction under study" section). We then outline the formal institutions - in other words, the regulatory framework for pasture use ("Formal property rights to pasture use" section); explore actors and their positions ("Actors" section); and outline the governance structures involved ("Governance structures in Municipality A (Kyrgyzstan)" section). In a final section ("Working rules to access summer grazing areas" section), we describe, in detail, the locally designed working rules governing pasture access in the Kyrgyz-Tajik transboundary region as well as how they contribute to the mitigation or the escalation of conflict.

\section{The status of the contested pasture resource}

Natural pasture is the main fodder source both in the Kyrgyz case study municipality, Municipality A, and the neighbouring Tajik Municipality B. The total pasture 
Table 1 List of respondents

\begin{tabular}{ll}
\hline State representatives & Pasture Department of the Ministry of Agriculture and Melioration of the Kyrgyz Republic, staff member \\
International experts & NGO Camp Ala-Too, staff member \\
& NGO Rural Development Fund, staff member \\
& UNDP, staff member \\
& Mountain Society Research Institute, University of Central Asia, staff member \\
& Municipality A municipality, mayor \\
& Batken District Pasture Committee, chairman \\
& Municipality A Municipality Pasture Committee, members \\
Local experts & Municipality A Pasture User Union, members \\
& Kyrgyz herders \\
& Tajik herders \\
&
\end{tabular}

area of Municipality A is 27,339 ha, which represents $55 \%$ of its entire area (NSC 2015). The pasture area comprises six major pastures located at distances between 23 and $67 \mathrm{~km}$ from Municipality A. They can be reached only via a road that crosses the Tajik municipality and its main village. All the pastures are used for summer grazing. The pastures are considered to be a scarce and limited resource. A current scientific assessment of the pastures' status is not available. However, local respondents report increasing levels of degradation that they estimate now affect $30-50 \%$ of the pasture area. The limited availability of pastures leads to conflict over grazing rights on those pastures. Table 2 lists the pasture areas in the study region and shows conflict incidence, as assessed by the two representatives of Municipality A's Pasture Committee interviewed. Of the six pastures in the study region, four are subject to conflicts over use rights. The intensity and frequency of conflict evidently varies in line with the current demand for specific sections of pasture. Our respondents reported, for instance, that a pasture that is little sought-after owing to the low quality of its forage plants is less affected by disputes.

\section{The transaction under study}

This paper explores transboundary access to summer pastures in the Kyrgyz-Tajik borderlands for livestock herders from both sides of the border. The transaction is associated with an escalating and at times violent conflict. Tajik and Kyrgyz pasture users hold different views on the distribution of property rights to these pastures. The transaction at the root of the conflict occurs mainly in summer, when herders from both sides of the border move livestock to summer pastures located near the contested border. The conflicting parties each lay claim to a legitimate right to use the same pasture areas. Interethnic competition for the use of the Kyrgyz-Tajik border pastures hence increases during the migration period.

A brief summary of the history of grazing rights in the case study region will aid understanding of the ongoing conflict. Under Soviet rule, all livestock was in the charge of large-scale state farms (sovkhoz) or so-called collective farms (kolkhoz). The kolkhoz management strictly regulated livestock operations, including the animals' annual summer migration to higher pastures. The farms employed herders who executed centrally designed plans for rangeland use. Usually, the herders were highly specialized, expert in herding a specific group of animals, such as heifers or ewes, for each of which a clearly delineated pasture use plan was drawn up. There were two collective farms in the case study region: the Tajik Isfara kolkhoz and the Kyrgyz Batken kolkhoz. Amongst other forms of cooperation, a formal agreement between the two kolkhozes permitted the Tajik kol$k h o z$ to put its livestock to graze on pastures allocated to the Kyrgyz kolkhoz. Accordingly, kolkhoz herders from both the Tajik village of Municipality B and the Kyrgyz village of Municipality A used the four large pastures

Table $\mathbf{2}$ List of summer pastures in the vicinity of the Municipality A and Municipality B communities

\begin{tabular}{|c|c|c|c|c|}
\hline Pasture name & Pasture category & Distance in kilometres from Municipality A & Pasture users & Conflict incidence \\
\hline Ulartoo & Summer & 26 & Kyrgyz & None \\
\hline Tooshkandyk & Summer/spring-autumn/winter & 23 & Kyrgyz & \\
\hline Bulak-Bashy & Summer & 35 & Kyrgyz/Tajik & Rare \\
\hline Chechektir & Summer & 53 & Kyrgyz /Tajik & Frequent \\
\hline Sharkyrama & Summer/spring-autumn/winter & 42 & Kyrgyz/Tajik & \\
\hline Kishemish & Summer/spring & 67 & Kyrgyz/Tajik & \\
\hline
\end{tabular}


located in the Kyrgyz Soviet Republic: Bulak-Bashy, Kishemish, Sharkyrama, and Chechektir.

\section{Formal property rights to pasture use}

Legislative and judicial reform in the wake of the breakup of the USSR caused a major disruption of grazing patterns in Municipality A and Municipality B. The demise of the Soviet Union in the early 1990s spelled the end of its collective farms. Livestock was distributed to the former kolkhoz workers who thereupon established small family farms. In consequence, the vast majority of residents of Municipality A in Kyrgyzstan and Municipality B in Tajikistan became livestock owners with a year-round need for forage. Since the expiry in 2007 of the "Agreement on Basic Intergovernmental Relations between the Republic of Tajikistan and the Kyrgyz Republic" (concluded in Dushanbe, July 12, 1996), Tajik nationals' access to and use of the transboundary Kyrgyz pastures is no longer formally regulated (Lim 2012). Both the exact location of the border and the ownership of said pastures are contested. One Soviet map from the period 1924-1939 defines the pastures as Tajik; another from 1958-1959 defines them as Kyrgyz; while the present Kyrgyz authorities consider the entire pasture area (i.e. all six aforementioned pastures) to be the property of the Kyrgyz Republic. This effectively deprives the Tajik municipality, Municipality B, of access to the summer grazing pastures and recurrently triggers conflict.

This disputed pasture use in the transboundary region is a direct consequence of historical institutional developments and the current state of Kyrgyz and Tajik foreign policy. Following the relocation of the Kyrgyz-Tajik border in 1955, and again in 1967, both the Tajik and Kyrgyz local communities came to consider the BulakBashy, Kishemish, Sharkyrama, and Chechektir pastures as their common property, or at the least they laid claim to traditional rights to use them. Since workers of both the Kyrgyz and the Tajik kolkhozes shared uncontested access to these pastures until 1989, they reasonably expect to be able to continue to use them. However, the Kyrgyz herders currently claim exclusive use rights based on both the location of the border on the aforementioned Soviet map from 1958-1959 and a law which they interpret as a prohibition of Tajik owners grazing livestock on said pastures, while the Tajik refer to the map from the period 1924-1939 as well as to their traditional rights to grazing those pastures. Currently, no political consensus on the exact location of the border is in sight and negotiations on the matter have come to a halt (Shodiev 2019). This finding is no surprise and supports findings by Reeves (2014) and Lim (2012), each of whom considers unclear borders a source of conflict, namely because, in the absence of clearly demarcated borders, contested property rights continue to fuel conflict over access to and use of natural resources in communities located in transboundary regions.

Current Kyrgyz legislation fails to offer adequate guidance on the question of pasture use by non-Kyrgyz nationals in the border region near the Tajik enclave (Lim 2012). Article 3 and Article 10 of the first version of the law "On Pastures" published January 26, 2009 (Kyrgyz Republic 2009), proclaim ownership of a "pasture ticket" (a receipt of payment for grazing fees levied by the local Pasture Committee) to be a prerequisite of pasture access. Article 12 of the same law makes provision for pasture use by foreigners: "foreign legal entities and individuals" may use "unused pastures on the basis of interstate and intergovernmental agreements ratified by the Jogorku Kenesh [parliament] of the Kyrgyz Republic". As no such intergovernmental agreements are currently in place, and as pasture tickets are available solely to local Kyrgyz herders resident within the jurisdiction of a community-based Pasture Committee, the above law introduced a de facto ban on foreign nationals' legal access to grazing. The Act No. 254 of December 12, 2011, amended the law of 2009; however, Article 12 was revoked. Since then, no further specific regulation of foreign nationals' access to and use of Kyrgyz pasture has come into force.

\section{Actors}

In this section, we outline all the actors involved in the transaction. We thereby deal with them in groups, in light of certain characteristics. In other words, we note each actor group's overall professional respectively economic interests, its stake in the summer grazing transaction, and its (and/or its rivals') deployment of strategy (or strategies) (see Table 3 for an overview).

Residents of both the Kyrgyz municipality A and the Tajik municipality B currently seek access to the Municipality A's summer pastures. Neither community can access alternative pastures for grazing its livestock. The Kyrgyz and Tajik pasture users engaged in summer migration to Municipality A's pastures fall largely into two groups: firstly, there are Tajik and Kyrgyz livestock raisers who drive their own animals to the summer pastures and whom we call "self-employed herders"; secondly, there are the Kyrgyz and Tajik "herding service providers" who generally do not own the animals in their charge during the summer migration period.

Self-employed herders usually raise livestock as a family business. Their herd size is sufficiently large to make independent summer migration profitable, for the latter requires substantial investment in equipment and staff and is therefore feasible only with a minimum herd size of 300 small ruminants (Wenzel 2016). In our analysis, we ignore the fact that some of the relatively wealthy 
Table 3 Conflict partners and their conflicting positions on transboundary pasture use around the Tajik enclave, Municipality B

\begin{tabular}{|c|c|c|c|c|}
\hline \multirow{3}{*}{$\frac{\text { Actor groups }}{\text { Pasture users }}$} & \multicolumn{4}{|c|}{ Actor characteristics } \\
\hline & & & & \\
\hline & $\begin{array}{l}\text { Actors' } \\
\text { nationality }\end{array}$ & $\begin{array}{l}\text { Actor groups' main economic } \\
\text { interest }\end{array}$ & $\begin{array}{l}\text { Actor groups' interest in summer } \\
\text { grazing transaction }\end{array}$ & Actor groups' shared strategy \\
\hline $\begin{array}{l}\text { Municipality A } \\
\text { herder/ self } \\
\text { employed }\end{array}$ & K & Herd weight gain & $\begin{array}{l}\text { Secure access to good quality } \\
\text { pastures; low number of co-users } \\
\text { of summer pastures }\end{array}$ & $\begin{array}{l}\text { Lobby for exclusion of Tajik herders from } \\
\text { Municipality A pasture }\end{array}$ \\
\hline $\begin{array}{l}\text { Municipality A } \\
\text { herder/ service } \\
\text { provider }\end{array}$ & K & $\begin{array}{l}\text { Increase income from herding } \\
\text { service sales }\end{array}$ & $\begin{array}{l}\text { Secure access to good quality } \\
\text { pastures; low number of co-users } \\
\text { of summer pastures }\end{array}$ & $\begin{array}{l}\text { Some incorporate additional unregistered } \\
\text { animals from Municipality B without } \\
\text { buying grazing permits for them } \\
\text { lobby for exclusion of Tajik herders from } \\
\text { Municipality A pasture }\end{array}$ \\
\hline $\begin{array}{l}\text { Municipality A } \\
\text { livestock owner/ } \\
\text { service buyer }\end{array}$ & K & $\begin{array}{l}\text { Herd weight gain; livestock security } \\
\text { during summer migration }\end{array}$ & $\begin{array}{l}\text { Presence of service providers with } \\
\text { access to high-quality pastures; } \\
\text { low grazing service fees }\end{array}$ & $\begin{array}{l}\text { Lobby for exclusion of Tajik herders from } \\
\text { Municipality A pasture }\end{array}$ \\
\hline $\begin{array}{l}\text { Municipality A } \\
\text { Pasture } \\
\text { Committee }\end{array}$ & K & $\begin{array}{l}\text { Sustainability of pasture use; } \\
\text { mitigate pasture use conflicts }\end{array}$ & Control number of pasture users & $\begin{array}{l}\text { Issue and control possession of Kyrgyz } \\
\text { herders' grazing permits: } \\
\text { accept grazing fee payments from Tajik } \\
\text { herders }\end{array}$ \\
\hline $\begin{array}{l}\text { Municipality B } \\
\text { livestock owner/ } \\
\text { service buyer }\end{array}$ & $\mathrm{T}$ & $\begin{array}{l}\text { Herd weight gain; livestock security } \\
\text { during summer migration }\end{array}$ & $\begin{array}{l}\text { Presence of service providers with } \\
\text { access to high-quality pastures; } \\
\text { low grazing service fees }\end{array}$ & $\begin{array}{l}\text { Buy grazing service from Kyrgyz herders } \\
\text { support Kyrgyz herding service providers } \\
\text { during passage through Municipality B and } \\
\text { at border checkpoints }\end{array}$ \\
\hline $\begin{array}{l}\text { Municipality B } \\
\text { herder/service } \\
\text { provider }\end{array}$ & $\mathrm{T}$ & $\begin{array}{l}\text { Increase income from herding } \\
\text { service sales }\end{array}$ & $\begin{array}{l}\text { Secure pasture access; low cost for } \\
\text { pasture access }\end{array}$ & $\begin{array}{l}\text { Unauthorized grazing } \\
\text { or } \\
\text { payment of informal grazing fee to the } \\
\text { Municipality A Pasture Committee }\end{array}$ \\
\hline $\begin{array}{l}\text { Municipality B } \\
\text { herder/ } \\
\text { self employed }\end{array}$ & $\mathrm{T}$ & $\begin{array}{l}\text { Herd weight gain; livestock security } \\
\text { during summer migration }\end{array}$ & $\begin{array}{l}\text { Secure pasture access; low cost for } \\
\text { pasture access }\end{array}$ & $\begin{array}{l}\text { Unauthorized grazing } \\
\text { or } \\
\text { payment of informal grazing fee to the } \\
\text { Municipality A Pasture Committee }\end{array}$ \\
\hline \multicolumn{5}{|c|}{ Governance structure } \\
\hline & $\begin{array}{l}\text { Actors' } \\
\text { nationality }\end{array}$ & $\begin{array}{l}\text { Actor groups' main professional } \\
\text { interest }\end{array}$ & $\begin{array}{l}\text { Actor groups' interest in summer } \\
\text { grazing transaction }\end{array}$ & Actor groups' shared strategy \\
\hline Border guards & K & $\begin{array}{l}\text { Prevent conflict with superiors; } \\
\text { protect Kyrgyz territory (pasture) } \\
\text { from foreign nationals' access }\end{array}$ & Secure extra income & $\begin{array}{l}\text { Request illegal fee for ignoring Tajik } \\
\text { herders' illegal pasture use }\end{array}$ \\
\hline $\begin{array}{l}\text { Pasture } \\
\text { Committee } \\
\text { members }\end{array}$ & K & $\begin{array}{l}\text { Ensure sustainable use of pastures; } \\
\text { prevent pasture use conflict }\end{array}$ & Secure extra income & $\begin{array}{l}\text { Request illegal grazing fee from Tajik } \\
\text { herders }\end{array}$ \\
\hline
\end{tabular}

herders sometimes integrate in their stock a smaller number of their neighbours' animals.

Herding service providers offer summer grazing on the remote summer pastures of Municipality A. This is usually their main source of income, since their personal livestock raising business is relatively small. Service buyers are individual livestock raisers whose herds are too small to make independent migration feasible. They xoften own only a very small number of animals for subsistence purposes. Herding service providers offer their service to small livestock raisers who pay a herding service fee per head of animal grazed. Often, cooperation between livestock raisers and herding service providers (often members of the same family) is long-standing.
The governing body is represented by members of the Pasture Committee, the executive elected body of the Pasture User Union in Municipality A, and to which the Kyrgyz legislation "On Pasture" allots the sole legal right to issue grazing permits ("pasture tickets"). Pasture Committees in Kyrgyzstan administer three types of seasonal pasture in the vicinity of herder communities: grazing in summer, in spring-autumn, and in winter. A key task of the Pasture Committee is to control access to the pasture areas and thereby ensure that animals are registered, in order then to draw up sustainable pasture use plans for the otherwise, often, overstocked pastures (Crewett 2012).

The last group of actors involved in the borderland conflict is the Kyrgyz and Tajik border guards who 
control passers-by at various checkpoints in the border region in our case study.

\section{Governance structures in Municipality A (Kyrgyzstan)}

The "On Pasture" law (passed January 26, 2009, No. 30) regulates the use of pasture for grazing purposes. The law declares the pastures in question to be the property of the Kyrgyz Republic and establishes a communitybased governance structure for pasture management. Each municipality has a community-based organization, the so-called Pasture User Union, which comprises all the local pasture users and is headed by its elected executive body, the so-called Pasture Committee. The Pasture Committee issues annual grazing permits ("pasture tickets") to the Kyrgyz community's herders. It is responsible for fixing and collecting grazing fees and for allocating and monitoring individual grazing rights. The grazing fee varies according to the type of animal grazed. A grazing schedule drawn up by the Pasture Committee regulates the seasonal allocation of grazing spots on the pastures. The Pasture Committee is in charge of pasture use and is responsible also for the resolution of any pasture-related conflict (Crewett 2012, 2015a; Kasymov et al. 2016).

All direct users of the Municipality A community's pastures, be they self-employed or herding service providers, must buy pasture tickets in accordance with the number of animals in their charge. At the time of data collection, the fee structure for the entire grazing period was as follows: 7 Kyrgyz som (0.10 USD) per head for small ruminants, 35 som (0.50 USD) per head for large ruminants, and 50 som (0.73 USD) per head for horses. Under the current management regime in place in Kyrgyzstan, pasture ticket registration is of major importance for pasture management, the data it provides being the basis on which both the pasture use plan (how much livestock/where) and the grazing schedule (pasture access/when) are drawn up. Pasture ticket registration hence allows the de facto stocking rates to be calculated for each grazing spot. In Municipality A, the grazing schedule and the grazing fees are agreed upon during meetings of its community Pasture Committee, in spring, prior to the summer migration. Neither Tajik herders nor their delegates are present at those meetings. Throughout the summer grazing period, representatives of the Pasture Committee make in situ permit checks. As mentioned above, there are currently no regulations in place on how to deal with the grazing interests-respectively the access to and use of specific sections of pasture-of those livestock raisers who are not resident within the jurisdiction of the relevant Kyrgyz Pasture Committee.

\section{Working rules to access summer grazing areas}

The grazing dilemma caused by poorly defined legal rights to pasture use in the Kyrgyz Tajik border region in
Municipality A and Municipality B has led Kyrgyz and Tajik herders and livestock raisers to develop three distinct sets of working rules (see Table 4 for an overview).

Firstly, we observe unauthorized grazing on the summer pasture by Tajik herders from Municipality B. These herders either are self-employed (i.e. have their own herd) or provide a herding service to citizens in their hometown of Municipality B. However, they neither hold a grazing permit nor are they lawfully registered users of the pastures. They do not acknowledge the Pasture Committee as the lawful governance body of the pastures, as they claim the pastures are in the territory of Tajikistan. A second line of defence amongst these Tajik herders is their own or their families' longstanding history of working those pastures during the Soviet period, which they perceive as amounting to "traditional use rights". If these herders come to the attention of the Pasture Committee representatives who patrol the pastures, they could be evicted for noncompliance with Kyrgyz legislation, which defines the pastures as Kyrgyz. Yet the Pasture Committee generally refrains from forcefully evicting Tajik herders from the summer pastures within its jurisdiction. The Pasture Committee members interviewed said they turn a blind eye to unauthorized grazing by unregistered herders, since their reluctant acceptance of it is a means to prevent further outbreaks of conflict.

Secondly, we find informally authorized grazing by Tajik livestock owners from Municipality B. This is a strategy by which Tajik herders acquire informal grazing permits from the Kyrgyz Pasture Committee by making payment of an "informal grazing fee". As Tajik citizens are not granted a formal right to obtain a regular pasture ticket, they are allowed to purchase informal grazing rights from the Kyrgyz Pasture Committee. The informal grazing arrangement is a verbal arrangement between the herder and a Pasture Committee member. The herder does not receive any formal proof of the payment. According to our interview partners, the grazing fee levied is 10 times higher than the amount Kyrgyz herders have to pay (300 som per sheep for Tajik herders and 35 som for Kyrgyz herders). The herder also has to pay for the use of each pasture separately. Migratory grazing usually involves the rotational use of three different pastures per year. Owners of regular pasture tickets pay once to obtain the right to use three different pastures. The informal grazing permit, however, has to be bought for each of the pastures. This means that Tajik herders not only pay 10 times the usual grazing fee but, in effect, 30 times the price a Kyrgyz herder pays.

Payment of the informal grazing fees protects Tajik herders if ever a Pasture Committee member attempts to evict them during his inspection of the summer pastures. But it certainly does not protect them from other 
Table 4 Distribution of benefits and sustainability impact of property rights institutions in place

\begin{tabular}{|c|c|c|}
\hline & $\begin{array}{l}\text { Ethics approval and consent to } \\
\text { participate }\end{array}$ & Ethics approval and consent to participate \\
\hline Unauthorized, unregistered use by Tajik citizens & $\begin{array}{l}\text { Beneficiaries: unauthorized herders } \\
\text { Losers: all pasture users who respect } \\
\text { the pasture use plan }\end{array}$ & $\begin{array}{l}\text { Too few animals are registered. Drafting the } \\
\text { correct pasture use plan is therefore impossible. }\end{array}$ \\
\hline Authorized, unregistered use & $\begin{array}{l}\text { Beneficiaries: Pasture Committee } \\
\text { members; buyers of grazing permits } \\
\text { Losers: Kyrgyz pasture users who } \\
\text { respect the pasture use plan }\end{array}$ & $\begin{array}{l}\text { Illegal practice; illegal income for the Pasture } \\
\text { Committee } \\
\text { Too few animals are registered. Drafting the } \\
\text { correct pasture use plan is therefore impossible. }\end{array}$ \\
\hline $\begin{array}{l}\text { Tajik livestock raisers' unregistered purchase of herding } \\
\text { services from Kyrgyz herding service providers }\end{array}$ & $\begin{array}{l}\text { Beneficiaries: herding service } \\
\text { providers with Tajik clients } \\
\text { Losers: herding service providers with } \\
\text { Tajik clients }\end{array}$ & $\begin{array}{l}\text { Too few animals are registered. Drafting the } \\
\text { correct pasture use plan is therefore impossible. }\end{array}$ \\
\hline
\end{tabular}

Kyrgyz pasture users' attempts to chase them off certain sections of the pasture. There is no legal basis for eviction attempts by the Pasture Committee, since neither the responsible state body nor the local Pasture User Union to which the Pasture Committee is formally accountable has ever passed regulations to this effect. The "informal grazing fee" is an unspoken reality nonetheless, and it represents an informal benefit for the Pasture Committee members.

Thirdly, we identify Kyrgyz herders' provision of unregistered herding and grazing services to Tajik livestock owners. This operation is framed by the regular herding contract between the herder service provider and his client, the buyer, which Kyrgyz contract partners likewise make: the herder registers each animal put in his charge and takes on the responsibility for its safety and well-being during the summer grazing period. However, Kyrgyz herders and Tajik livestock owners negotiate the service fee themselves, which is very profitable for the Kyrgyz herder. According to our interviewees, the Tajik service buyer has to pay a herding fee of 300 som, i.e. 6.6 times the fee a Kyrgyz livestock owner pays for the same service. Tajik and Kyrgyz livestock owners and herders cooperate closely on this project. The Kyrgyz herding service provider and the Tajik client (livestock owner) arrange the date, place, and time where the livestock will be gathered. The client and Kyrgyz herder meet shortly before the latter crosses the border into the Municipality B enclave. The Tajik client supports the usually difficult passage of the Kyrgyz herder's herd through the Tajik municipality border area, so as to avoid problems such as the possible theft of Kyrgyz animals. After passing through Municipality B, the Tajik clients' animals are incorporated into the Kyrgyz herder's herd. One or two Tajik helpers then help the herder make the second Tajik border crossing to reach his final destination, the pasture.

Grazing of this sort is considered illegal by the majority of the Kyrgyz herders and leads to conflict amongst the Kyrgyz herders and the local Pasture Committee. It is a violation of the regulations if a Kyrgyz herder illegally brings a number of unregistered animals to the pastures and likewise if he fails to pay the Kyrgyz Pasture Committee a grazing fee for each animal (pasture ticket purchase).

\section{De-escalation effects of the working rules}

In allocating specific pasture rights to both Kyrgyz and Tajik herders, the Pasture Committee prevents direct competition between the two groups for the exact same grazing plots. In light of current tensions in the area, we believe this to be an important factor for conflict mitigation, or at the least for preventative de-escalation. The Pasture Committee also buffers conflict amongst Kyrgyz and Tajik herders, as the Kyrgyz, upon meeting Tajik herders with informal grazing permits on the pastures, approach the Pasture Committee to complain about it having granted access rights to their rivals. While the activities of the Pasture Committee seem to violate formal regulations-and lead also to illegal payments ("backhanders" or bribes) to Pasture Committee membersthey serve to lessen direct confrontation between Tajik and Kyrgyz herders. We believe that in the absence of the Pasture Committee's inclusive pasture registration scheme there would be more direct and open conflict between Tajik and Kyrgyz pasture users.

The Pasture Committee does not strictly enforce Kyrgyz-only herding on the summer pastures under its jurisdiction. Our data shows that the Pasture Committee, in order to avoid further conflict, does not forcefully evict the Tajik herders from the pastures within its jurisdiction. We conclude that the Pasture Committee, in drawing up locally designed rules that pragmatically extend grazing rights to Tajik herders, substantially reduces the potential for local conflict and, undeniably, also the frustration Tajik herders would feel if they were completely denied access to the summer pastures.

\section{Escalation effects of the working rules}

The Pasture Committee has an ambiguous role. We note that, although some of its actions partly mitigate conflict, they also at times aggravate conflict. 
Firstly, we observe non-consensual decision-making on pasture rights. There is neither formal legal provision in Kyrgyzstan nor clear consensus amongst the Kyrgyz herders for Tajik herders' gaining de facto access to grazing on contested transboundary pastures. The law does not expressly sanction Kyrgyz herders who graze animals owned by non-Kyrgyz nationals, but there is evidently a need for further clarification by legal experts of the legality (or not) of herding service provision to foreign nationals, as well as for a definitive statement on the matter by the state authorities. The Pasture Committee's tolerance of Tajik access in return for informal grazing fee payments does not have the approval of the Kyrgyz community. Our fieldwork suggests that the tacitly accepted presence of Tajik herders on summer pastures contributes to conflict aggravation.

Secondly, the current rules in place do not foster sustainable pasture use, as stocking rates are not restricted. There are a great many non-registered animals on the pastures because the Pasture Committee issues informal grazing permits without ensuring in parallel that the corresponding quantity of livestock is incorporated (i.e. calculated for) in its pasture use plans. In other words, the Pasture Committee is not in a position either to formulate a fully transparent grazing schedule or to publicly communicate approved stocking rates, because it cannot officially include in its pasture use plans the livestock of those Tajik herders from whom it accepts "informal grazing fees", i.e. "backhanders" or bribes. The Pasture Committee's locally designed rules contribute, therefore, to further aggravating the demand for-as well as the severe depletion of-the pastures within its jurisdiction.

Thirdly, the costs and revenue distribution resulting from informal grazing regulation is considered unfair by the Kyrgyz herders (or at least by those who do not participate in illegally grazing Tajik-owned animals). As many of our respondents see it, the overall Kyrgyz herders' community has to carry the cost of the increase in the number of animals allowed onto the summer pastures. A complete ban on Tajik-owned livestock would be preferable to some, as currently only the Pasture Committee itself and the service providers who herd Tajik livestock reap any benefits. It seems likely that the unofficial (i.e. non-registered) provision of grazing rights to Tajik herders is a source of additional undeclared income for certain Pasture Committee members. Evidently, the Pasture Committee thereby exploits the Tajik herders' lack of alternatives, levying a grazing fee from them that is not only illegal but also extraordinarily high, namely 30 times the fee the Kyrgyz herders pay. The Pasture Committee thereby respects the rules of the market, however, inasmuch as it levies the exact same amount that an illegal Kyrgyz herding service provider would charge a Tajik livestock owner (namely 10 times the fee a Kyrgyz client has to pay).

However, we find that Tajik herders have no choice but to accept the high service fee requested by Kyrgyz herders. Service provision to Tajik clients causes major arguments between Kyrgyz herders, since those who do not make money from illegally grazing Tajik livestock decry the practice.

We note mixed outcomes of the locally designed rules for transboundary pasture access. We believe that further conflict between Tajik and Kyrgyz herders is reduced in part, since Tajik herders gain a grazing opportunity, albeit an informal and insecure one. On the other hand, we observe that informal grazing permits aggravate and multiply conflict between Kyrgyz herders and the Kyrgyz Pasture Committee and they exacerbate depletion of the pastures, to the detriment of the local community. Local Kyrgyz herders/Pasture User Union members do not accept the Pasture Committee's conflict mitigation strategy, since they consider that it fails to take into account their interests and those of the broader Municipality A community. These additional conflicts within the Kyrgyz community complicate the underlying tensions between the pasture users on each side of the Kyrgyz-Tajik border.

Sustainable pasture use-first and foremost the prevention of overstocking-is by no means at the top of the local policymakers' agenda. We find that no clear rules are in place on the grazing of non-locally registered animals, on formal options for pasture use by foreign nationals, or on regulation of the herding business.

We also note that community-based management does not prevent those holding office within communitybased organizations (notably, Pasture Committee members) from circumventing the law or diverting public revenue for their own benefit.

The locally designed rules now in place go somewhat further than those enshrined in the law "On Pastures" of 2009. They cover the matter of commercial non-local herding. Yet the rules, being inadequate, invite violation. In other words, the fact that livestock owned and/or herded by Tajik citizens cannot be registered means it cannot be incorporated in any pasture use plans. And this-since Tajik livestock raisers inevitably have to find alternative solutions-leads to bribery and overstocking.

We find positive and critical aspects in the pragmatic rule sets drawn up by the Pasture Committee. Two interpretations are possible. One could consider that the Pasture Committee's rulemaking fosters illegal grazing, the pocketing of bribes, and failure to enforce lawful use of the Kyrgyz pastures. One could equally acknowledge that the Pasture Committee plays an important role in conflict regulation. The locally designed rules are pragmatic and locally applicable, and 
they mitigate inter-ethnic tension in relation to pasture use. We see, however, that the rules in place fail to improve the sustainability of pasture use, fail to fairly distribute benefits from the use of the commons (i.e. the pastures traditionally maintained for the public good), and thereby cause ongoing conflict amongst the Kyrgyz Pasture Committee, its constituencies, and the Kyrgyz herders themselves.

\section{Discussion}

We find the Kyrgyz community-based Pasture Committees to be a key actor in the conflict situation. The Pasture Committee, being the only local-level organization concerned with pasture administration, is accepted as the major governance body by the Kyrgyz and, surprisingly, by a number of Tajik herders; for given that Tajik herders dispute Kyrgyzstan's territorial claim to the pastures, one could expect them to dispute the authority of the Kyrgyz Pasture Committee.

Our study shows that the Pasture Committee is engaged in institutional design in relation to pasture use. In general, the Kyrgyz law "On Pasture" (2009) encourages the design of local pasture use regulations by the local pasture user community and the executive local Pasture Committee. Our study finds that the Kyrgyz Pasture Committee and Kyrgyz herding service providers design working rules in order to cope with the pasture demand amongst Tajik livestock raisers. Local-level working rule design by the Kyrgyz Pasture Committee approves extra-legal grazing of Tajik animals by Kyrgyz and Tajik herders in exchange for illegal extra payments to the Pasture Committee and high service fees to the Kyrgyz herders. Those rules partly serve to prevent the further escalation of open conflicts. Options for some members of the Kyrgyz community, including Pasture Committee members, to seek to make a profit may, however, cause future conflict aggravation. We also find that these rules completely fail to control animal numbers and so cannot ensure sustainable use of the natural (pasture) resource.

Our study is the first scientific study to analyse the impact of local-level rule design on conflicts surrounding summer pasture use in the Kyrgyz-Tajik borderland. It shows that, contrary to media coverage and other reports that generally refer only to contested land rights for cropping purposes and/or the conflicts occurring in relation to the construction of a road that crosses the Tajik enclave of Municipality B, summer pastures are in fact a massively contested issue and a cause of conflict in the Kyrgyz-Tajik borderlands. Our findings therefore support those of Lim (2012), author of the to-date sole published study of transboundary pasture management in the Kyrgyz-Tajik borderland. While Lim explores gaps in formal regulation in great detail, our study looks at the institutional design on the ground, in other words, at how local administrators muddle through, designing rules ad hoc to compensate for gaps in the current legislation.

Lim (2012) emphasizes the need for international agreements on border location and pasture management institutions and organizations. Our study goes a step in the same direction, specifying the need for further regulation of Kyrgyz herders' service provision to Tajik livestock raisers and the importance of finding a legal strategy for integrating foreign raisers' livestock into Kyrgyz herd management plans.

Yet the working rules in place are not a sustainable solution to long-term conflict resolution, as their design does not respect important criteria for sustainable rule design.

Our study raises some issues concerning the effectiveness of community-based pasture management under the conditions prevailing in Kyrgyz border communities. It demonstrates the ability of local-level rule designers to draft locally designed rules. The rules thus designed go further than the operative regulations enshrined in the "On Pastures" law of 2009. Community-based management is meant to support locally tailored rule design by local-level decision-makers as this is believed to lead to more suitable rule configurations. The case study observed here is therefore in line with theoretical assumptions on the local appropriateness of locally designed rules (Bardhan and Mookherjee 2010; Agrawal and Ostrom 2001). We see, however, that local rule design does not otherwise fulfil the hopes associated with community-based natural resource management, for this includes local control of authorities' leeway for discretion and of decision-makers and resource flows. The designed rules neither support transparent local-level management of public resources nor foster community involvement. Our study therefore is in agreement with findings from Crewett (2015a, 2015b), who reported on difficulties that Pasture Committees face in attempting to organize sustainable pasture use rotations and the inability of local residents to monitor actions taken by the Pasture Committee.

\section{Conclusion}

In our case study, we find a formal institutional framework with gaps in three important areas: border demarcation, transnational grazing rights, and herding service provision regulations. The working rules in place are not fit either to mitigate transboundary conflict or to ensure sustainable pasture use. We therefore conclude that there is a need for intergovernmental agreement on pasture use in the region under study in order to permit herders of both nationalities rangeland access for grazing. In the absence of such agreement, and assuming 
that the pastures continue to be considered Kyrgyz territory, it might be helpful to explore regulatory strategies for the legal access of Tajik-owned livestock to Kyrgyz pastures. Such regulation would bring clear benefits to the entire Kyrgyz pasture user community. Conceivable is the introduction of higher grazing fee rates for nonlocal pasture users, as this would increase the income of the Pasture User Union and could support investment in pasture infrastructure or winter forage banks. Herding service fees should be the same for both Tajik and Kyrgyz livestock raisers. Both the above regulations would decrease local-level conflict in relation to Tajik pasture use. We personally propose, moreover, that these regulations be complemented by strictly enforced livestock border controls at Veterinary Border inspection posts.

In more general terms, it is evident that the strict regulation of livestock numbers on the summer pastures is imperative. Increasing grazing fees overall would possibly be the most effective way to motivate herders to reduce their stock. A sliding grazing fee that makes herding very large numbers of animals less profitable than at present might help meet the needs of the most disadvantaged members of the community, i.e. impoverished subsistence farmers.

\section{Authors' contributions \\ GK and WC developed the research question. GK initiated, designed, and carried out the empirical study. GK participated in the data analysis and data interpretation. GK wrote the first draft of the paper. WC participated in the data analysis and data interpretation. WC prepared the final draft of the manuscript. Both authors read and approved the final manuscript.}

\section{Funding}

The authors are grateful for the funding by the European Council by means of an Erasmus Mundus-grant under the EMA 2 Euro-Asian CEA Consortium call. We acknowledge support by the German Research Foundation (DFG) and the Open Access Publication Fund of Humboldt-Universität zu Berlin.

\section{Availability of data and materials}

The datasets used and analysed during the current study are available from GK on reasonable request.

\section{Ethics approval and consent to participate}

Not applicable

\section{Consent for publication}

Not applicable

\section{Competing interests}

The authors declare that they have no competing interests.

\section{Author details}

${ }^{1}$ Naryn State University named after S.Naamatov, Naryn, Kyrgyz Republic.

${ }^{2}$ Humboldt-Universität zu Berlin, Unter den Linden 6, 10099 Berlin, Germany.

Received: 27 November 2018 Accepted: 6 June 2019

Published online: 11 October 2019

\section{References}

Abdullaev, Iskandar, Herath Manthrithilake, and Jusipbek Kazbekov. 2006. Water security in Central Asia: Troubled future or pragmatic partnership? Presented at International Conference "The Last Drop?" Water, security and sustainable development in Central Eurasia, December 1, in Den Haag. https://www. academia.edu/441416/Water_Security_In_Central_Asia_Troubled_Future_or_ Pragmatic_Partnership. Accessed 22 May 2018.
Agrawal, Arun, and Elinor Ostrom. 2001. Collective action, property rights, and decentralization in resource use in India and Nepal. Politics and Society 29 (4): 485-514. https://doi.org/10.1177/0032329201029004002.

Bardhan, Parnab, and Dilip Mookherjee. 2010. Decentralization and local governance in developing countries: A comparative perspective. Cambridge: MIT Press.

Beyene, Fekadu. 2009. Collective action in water-point management: The case of pastoral and agropastoral communities in eastern Ethiopia. Natural Resources Forum 33 (3): 175-188. https://doi.org/10.1111/j.1477-8947.2009.01223.x.

Bichsel, Christine. 2009. Conflict transformation in Central Asia: Irrigation disputes in the Ferghana valley. London: Routledge.

Bogner, Alexander, Beate Littig, and Wolfgang Menz. 2009. Interviewing experts. London: Palgrave Macmillan.

Bromley, Daniel W. 1991. Environment and economy: Property rights and public policy. Oxford: Blackwell.

Cabot, Charlène. 2017. Climate change, security risks and conflict reduction in Africa. Berlin, Heidelberg: Springer.

Commons, John Rogers. 1931. Institutional economics. American Economic Review 21 (4): 648-657.

Crewett, Wibke. 2012. Improving the sustainability of pasture use in Kyrgyzstan. Mountain Research and Development 32 (3): 267-274. https://doi.org/10.1659/ MRD-JOURNAL-D-11-00128.1.

Crewett, Wibke. 2015a. Introducing decentralized pasture governance in Kyrgyzstan: Designing implementation rules. Environmental Science \& Policy 53: 215-224. https://doi.org/10.1016/j.envsci.2014.12.009.

Crewett, Wibke. 2015b. Street-level bureaucrats at work: A municipality-level institutional analysis of community-based natural resource management implementation practice in the pasture sector of Kyrgyzstan. Sustainability 7 (3): 3146-3174. https://doi.org/10.3390/su7033146.

Dörre, Andrei. 2016. Changes in the relationship between borders and pastoral mobility in mountain regions of Central Asia. In Mapping transition in the Pamirs: Changing human-environmental landscapes, ed. Hermann Kreutzmann and Teiji Watanabe, 95-112. Advances in Asian Human-Environmental Research. Cham: Springer.

Eggertsson, Thrainn. 1996. A note on the economics of institutions. In Empirical studies in institutional change. In Political economy of institutions and decisions, ed. Lee J. Alston, Thrainn Eggertsson, and Douglass C. North, 6-24. Cambridge: Cambridge University Press.

Fleetwood, Steve. 2008. Institutions and social structures. Journal for the Theory of Social Behaviour 38 (3): 241-265.

Furubotn, Eirik G., and Svetozar Pejovich. 1972. Property rights and economic theory: A survey of recent literature. European Review of Agricultural Economics 10 (4): 1137-1162.

Hagedorn, Konrad. 2008. Particular requirements for institutional analysis in nature-related sectors. European Review of Agricultural Economics 35 (3): 357384. https://doi.org/10.1093/erae/jbn019.

Hagedorn, Konrad, Katja Arzt, and Ursula Peters. 2002. Institutional arrangements for environmental cooperatives: A conceptional framework. In Environmental cooperation and institutional change: Theories and policies for European agriculture, ed. Konrad Hagedorn, 3-25. Cheltenham: Edward Elgar Publishing https://www. cabdirect.org/cabdirect/abstract/20023096337. Accessed 22 May 2018.

Hamidov, Ahmad and Thiel, Andreas, eds. 2011. Institutional change in transition: Review of conditions for sustainable water consumers associations in semiarid Uzbekistan. European Regional Conference of the International Association for the Study of the Commons. http://dlc.dlib.indiana.edu/dlc/ handle/10535/7688.

Hundie, Bekele. 2010. Conflicts between Afar pastoralists and their neighbors: Triggers and motivations. International Journal of Conflict and Violence 4 (1): 134-148.

Kasymov, et al. 2016. Central Asia: Kyrgyzstan and the learning experience in the design of pastoral institutions. Revue Scientifique et Technique 35 (2): 511-521. https://doi.org/10.20506/rst.35.2.2538.

Kerven, Carol, Bernd Steimann, Chad Dear, and Laurie Ashley. 2012. Researching the future of pastoralism in Central Asia's mountains: Examining development orthodoxies. Mountain Research and Development 32 (3): 368 377. https://doi.org/10.1659/MRD-JOURNAL-D-12-00035.1.

Kerven, Carol, Steimann, Bernd, Chad Dear, and, I. Rahim. 2011. Pastoralism and farming in Central Asia's Mountains: A research review. MSRC Background Paper (1) University of Central Asia: Bishkek. doi: https://doi.org/10.5167/uzh-52730.

Kyrgyz Republic. 2009. Zakon Kyrgyzskoi Respubliki 'O pastbishchakh' N 30. 26 yanvarya 2009 goda [Law of the Kyrgyz Republic 'On pasture', No. 30, 26 January 2009] Ministry of Justice of the Kyrgyz Republic, Bishkek. 
Libecap, Gary D. 1989. Contracting for property rights. Cambridge: Cambridge University Press.

Lim, Michelle. 2012. Laws, institutions and transboundary pasture management in the High Pamir and Pamir-Alai mountain ecosystem of Central Asia. Law, Environment and Development Journal 8 (1): 43-58 www.lead-journal.org/ content/12043.pdf. Accessed 22 May 2018.

Matveeva, Anna. 2017. Divided we fall ... or rise? Tajikistan-Kyrgyzstan border dilemma. Cambridge Journal of Eurasian Studies 1: 1-20. https://doi.org/1 $0.22261 / 94 \mathrm{D} 4 \mathrm{RC}$

Mayring, Philipp. 2000. Qualitative content analysis [28 paragraphs]. Forum: Qualitative Social Research 1 (2): Art. 20 http://nbnresolving.de/urn:nbn:de: 0114-fqs0002204. Accessed 1 May 2018.

Mosello, Beatrice. 2008. Water in Central Asia: A prospect of conflict or cooperation? Journal of Public and International Affairs 19: 151-174 Accessed 22 May 2018.

NSC (National Statistical Committee of the Kyrgyz Republic) (2015)Batken Oblast. http://www.stat.kg/en/opendata/category/487/. Accessed 25 Oct 2018.

Ostrom, Elinor. 1990. Governing the commons. The evolution of institutions for collective action. Cambridge: Cambridge University Press.

Ostrom, Elinor. 2005. Understanding institutional diversity. Princeton: Princeton University Press.

Prager, Katrin. 2010. Applying the institutions of sustainability framework to the case of agricultural soil conservation. Environmental Policy and Governance 20 (4): 223-238. https://doi.org/10.1002/eet.548.

Reeves, Madeleine. 2014. Border work: Spatial lives of the state in rural Central Asia. 1st ed. Ithaca: Cornell University Press.

Sehring, Jenniver. 2009. The politics of water institutional reform in neopatrimonial states: A comparative analysis of Kyrgyzstan and Tajikistan. Wiesbaden: VS Verlag für Sozialwissenschaften.

Haydar, Shodiev (2019) Земля, как камень преткновения: Что происходит на таджикско-кыргызской границе на самом деле? [Land as a stumbling block: What is really going on at the Tajik-Kyrgyz border?] Media Group AsiaPlus Tajikistan. 16 March 2019. https://news.tj/ru/news/tajikistan/security/201 90316/zemlya-kak-kamen-pretknoveniya-chto-proishodit-na-tadzhikskokirgizskoi-granitse-na-samom-dele. Accessed 18 Mar 2019.

Toktomushev, Kemel. 2017. Promoting social cohesion and conflict mitigation: Understanding conflict in cross - Border areas of Kyrgyzstan and Tajikistan, University of Central Asia, Graduate School of Development, Institute of Public Policy and Administration, Working Paper no. 40. https://www. ucentralasia.org/Content/Downloads/UCA-IPPA-WP-40_ PromotionCrossBorderSocialCohesion_Eng.pdf. Accessed 6 May 2018.

Vinogradov, Sergei, and Vance P.E. Langford. 2001. Managing transboundary water resources in the Aral Sea Basin: In search of a solution. International Journal of Global Environmental Issues 1 (3/4): 345-362. https://doi.org/10.15 04/IJGENVI.2001.000984.

Wenzel, Bettina. 2016. Existenzsicherung und Risikomanagement im ländlichen Raum Nordkirgistans. Eine multidimensionale geographische Analyse. Berlin: Free University Berlin.

Wiebe, Keith D., and Ruth Meinzen-Dick. 1998. Property rights as policy tools for sustainable development. Land Use Policy 15 (3): 203-215. https://doi.org/10.1 016/S0264-8377(98)00014-3.

Williamson, Oliver E. 2000. The new institutional economics: Taking stock, looking ahead. European Review of Agricultural Economics 38 (3): 595-613. https:/doi. org/10.1257/jel.38.3.595.

Zelalem, Muchie, and Endalcachew Bayeh. 2014. Traditional conflict resolution mechanisms among Ambo Woreda Communities. International Journal of Research (IJR) 1 (11): 822-829.

\section{Publisher's Note}

Springer Nature remains neutral with regard to jurisdictional claims in published maps and institutional affiliations.

\section{Submit your manuscript to a SpringerOpen ${ }^{\circ}$ journal and benefit from:}

- Convenient online submission

- Rigorous peer review

- Open access: articles freely available online

- High visibility within the field

- Retaining the copyright to your article

Submit your next manuscript at $\boldsymbol{\nabla}$ springeropen.com 